\title{
Integration of soil, crop and weed management in low-external-input farming systems
}

\author{
M LIEBMAN \& A S DAVIS \\ Iowa State University, Department of Agronomy, 3218 Agronomy Hall, Ames, IA, 50011-1010, USA
}

Received 28 June 1999

Revised version accepted 20 September 1999

\section{Summary}

Greater adoption and refinement of low-external-input (LEI) farming systems have been proposed as ways to ameliorate economic, environmental and health problems associated with conventional farming systems. Organic soil amendments and crop diversification are basic components of LEI systems. Weed scientists can improve the use of these practices for weed management by improving knowledge of four relevant ecological mechanisms. First, multispecies crop rotations, intercrops and cover crops may reduce opportunities for weed growth and regeneration through resource competition and niche disruption. Secondly, weed species appear to be more susceptible to phytotoxic effects of crop residues and other organic soil amendments than crop species, possibly because of differences in seed mass. Thirdly, delayed patterns of $\mathrm{N}$ availability in LEI systems may favour large-seeded crops over small-seeded weeds. Finally, additions of organic materials can change the incidence and severity of soil-borne diseases affecting weeds and crops. Our research on LEI sweetcorn and potato production systems in central and northern Maine (USA) suggests that these mechanisms can reduce weed density and growth while maintaining crop yields. Low-external-input farming systems will advance most quickly through the application of interdisciplinary research focused on these and other ecological mechanisms.

Keywords: crop diversification, organic soil amendments, phytotoxicity, seed mass.

\section{Introduction}

At the close of the twentieth century, agricultural weed management is diverging in two distinct directions. In one set of farming systems, which we will call conventional, farmers rely primarily on herbicides to suppress weeds. This approach is exemplified by the extensive maize (Zea mays L.)/soyabean (Glycine max (L.) Merr.) systems of the mid-western USA, where $>110$ million $\mathrm{kg}$ of herbicide active ingredients are applied annually to $>95 \%$ of the area planted with those two crops (Lin et al., 1995). In a second set of farming systems, which we will call low 
external input (LEI), herbicides are largely or entirely avoided, and weeds are suppressed largely through physical and ecological tactics. Although LEI systems occupy only a small portion of the agricultural landscape in most regions, they are becoming increasingly prominent as economic, regulatory and biological pressures on conventional farming systems intensify.

Refinement and greater adoption of LEI practices have been proposed as ways to address low farm profitability, environmental and health risks of agrochemical exposure and shifts in populations and communities of weeds and other pests towards pesticide-resistant genotypes and species (Benbrook, 1996). These concerns and expanding world markets for organic products (Geier, 1998) provide important incentives for improving weed management in LEI farming systems. Owing to a long-standing paucity of weed science research relevant to LEI systems (Benbrook, 1996), strategies to improve weed management are among the top research priorities of LEI farmers (Organic Farming Research Foundation, 1998). Weed scientists should recognize the exceptional opportunity that currently exists to address the self-identified needs of LEI farmers.

When reliance on herbicides is reduced or eliminated, tillage and cultivation generally become more important for weed suppression. In response to growing interest in LEI farming systems, information concerning weed management with tillage and cultivation machinery has become more accessible in recent years (Mohler, 1993; Mohler et al., 1997; Bowman, 1998). Tillage and cultivation must be used judiciously, however, as frequent and intensive soil disturbance can accelerate loss of soil organic matter, destroy soil aggregates, increase soil erosion and degrade soil in other ways. By shifting some of the burden of crop protection from herbicides, tillage and cultivation to ecological approaches, requirements for purchased inputs can be reduced, soil and water quality can be better protected, risks of crop loss can be lessened and selection for adapted weed species and genotypes can be minimized (Liebman \& Gallandt, 1997).

In this article, we examine the impacts on weeds of several practices that are common components of many LEI farming systems: diversifying crop sequences with multispecies rotations, cover crops and intercrops, and amending soil with crop residues, animal manures and composts. We emphasize ecological mechanisms, whereby these farming practices can contribute to weed suppression, with particular attention to impacts on weed regeneration, resource use, allelopathic interactions and soil-borne pathogens. We conclude with two examples of how crop diversification and organic soil amendments can be used in concert to improve weed management for sweetcorn and potato production. The information we present is drawn almost exclusively from temperate regions, which we know best, but our intention is to stimulate discussion and research that will foster the use of multitactic, ecologically based weed management strategies in a range of farming systems worldwide.

\section{Regeneration niches and resource competition}

The effects of crop diversification practices on weeds have been reviewed elsewhere (Liebman \& Dyck, 1993; Liebman \& Ohno, 1998; Teasdale, 1998), but several key points merit discussion here.

\section{Crop rotation}

Grubb's (1977) concept of 'regeneration niche' provides a useful context for understanding how crop rotation can improve weed management. A regeneration niche comprises a species-specific 
set of environmental conditions required to ensure that a mature plant is replaced by an individual of the next generation. Because recruitment of new individuals is most often successful if climatic conditions match a weed's ecophysiological tolerances and established competitors are weak or absent, the regeneration niches of many plants have a strong temporal component and are linked to patterns of soil disturbance and vegetation removal. Most weed species exhibit characteristic pulses of germination and growth (Egley \& Williams, 1991; Popay et al., 1995) in response to environmental factors, such as soil temperature, light intensity and light quality, which change with the season, tillage and canopy development (Pons, 1992; Forcella et al., 1997).

By rotating crops with different planting dates and growth periods, contrasting competitive characteristics and dissimilar management practices, the regeneration niche of different weed species can be disrupted and increases in particular weed species prevented. For example, Blackshaw (1994) reported that Bromus tectorum (L.) density remained relatively stable when winter wheat (Triticum aestivum L.) was rotated with oilseed rape (Brassica napus L.), whereas the density of the weed increased rapidly when wheat was grown continuously. Similarly, Covarelli \& Tei (1988) noted that seedling and seed densities of Echinochloa crus-galli (L.) Beauv. were lower in a winter wheat/maize rotation than in continuous maize. Schreiber (1992) found that Setaria faberi Herrm. seedling density tended to be greatest in continuous maize, intermediate in a 2-year maize/soyabean rotation and lowest in a 3-year maize/soyabean/winter wheat rotation. The results of these and other studies do not resolve questions of how many and what types of crops should be included in a rotation for maximum weed suppression, but they encourage further research into those questions.

Perennial forage crops constitute important components of many crop rotation systems and offer opportunities to suppress weeds through competition (Risser, 1969), mowing (Norris \& Ayres, 1991) and grazing (Dowling \& Wong, 1993). Furthermore, because there is little soil disturbance when a forage crop occupies a field, the germination of many weed species is suppressed relative to tilled conditions (Roberts \& Feast, 1973) and, consequently, few new weed seeds may be added to the soil seedbank, while seed predation and decay continue to occur. The combined effects of these factors can reduce annual weed densities appreciably. In a survey of Manitoba and Saskatchewan farmers, $83 \%$ of the respondents reported fewer weeds in grain crops after forages (especially lucerne, Medicago sativa L.) than after grain crops; $67 \%$ reported higher grain yields after forages than after grain crops (Entz et al., 1995). In field experiments, weed seed populations were found to decline by $\approx 99 \%$ for Avena fatua L. after 3 years of perennial ryegrass (Lolium perenne L.)/white clover (Trifolium repens L.) pasture (Wilson \& Phipps, 1985), 47\% for Abutilon theophrasti Medikus after 2 years of lucerne (Lueschen et al., 1993) and 47\% for Sinapis arvensis L. after 1.5 years of bromegrass (Bromus inermis Leyss.) (Warnes \& Andersen, 1984). In each case, maintenance of the forage stands for longer periods of time had little additional effect on weed seed mortality. Inclusion of forage crops in rotations should therefore be expected to reduce, but not eliminate, seed populations of weeds typically found in arable crops, although some species decline more rapidly than others.

\section{Cover crops}

Cover crops occupy a field before or after periods of 'main crop' production and can be integrated into both temperate and tropical production systems (Thurston, 1997; Bowman et al., 1998; Teasdale, 1998). In addition to improving soil physical characteristics, reducing nutrient leaching and erosion, and adding $\mathrm{N}$ (in the case of legume species), cover crops can suppress 
weed establishment and growth, thereby reducing the number of weed seeds and vegetative propagules infesting succeeding crops. Cover crops suppress weeds by competing for the use of growth resources, changing environmental factors that affect weed germination and establishment and releasing phytotoxins, a process that will be discussed later.

Hairy vetch (Vicia villosa Roth) is used by many LEI farmers in temperate regions as a winter annual cover crop in grain and vegetable production systems (Bowman et al., 1998). Teasdale \& Daughtry (1993) reported that live hairy vetch reduced weed density by $70-78 \%$ and reduced weed biomass by $52-70 \%$ compared with a fallow treatment. Measurements made after vetch had completed the majority of its growth showed that an average of $87 \%$ of sites beneath the cover crop received $<1 \%$ of unobstructed sunlight. Hairy vetch decreased the red $(660 \mathrm{~nm})$ to far-red $(730 \mathrm{~nm})$ ratio of transmitted light by $70 \%$ and reduced daily maximum soil temperature and diurnal soil temperature amplitude. Reductions in weed density and biomass were attributed to light extinction and changes in light quality and soil thermal regime.

Weed suppression by cover crops can be directly proportional to cover crop growth and canopy production, as shown by data from McLenaghen et al. (1996), who sowed five winter cover crops or let ground lie fallow after ploughing pasture. The quantity of ground cover produced by weeds was inversely proportional to that produced by the crops (Fig. 1). In the fallow treatment without a crop, weeds covered $52 \%$ of the ground area. In contrast, the most weed-suppressive cover crop, white mustard (Sinapis alba L.), produced 92\% ground cover and reduced ground cover by weeds to just $4 \%$. In addition to light competition, $\mathrm{N}$ competition may also have reduced weed growth, as most of the cover crops used were shown to be effective in capturing soil nitrate.

\section{Intercrops}

Intercropping is practised by LEI farmers in both developing and industrial countries and can, in many cases, reduce weed density and growth more effectively than sole crops (Liebman \& Dyck, 1993). Intercrops that are particularly effective at suppressing weeds capture a greater share of available resources than sole crops. Abraham \& Singh (1984) found, for example, that a grain sorghum (Sorghum bicolor (L.) Moench.)/fodder cowpea (Vigna unguiculata (L.) Walp.) intercrop intercepted more light, captured greater quantities of macronutrients (,$P$ and $K$ ), produced higher crop yields and contained lower weed densities and less weed dry matter compared with sole-cropped sorghum.

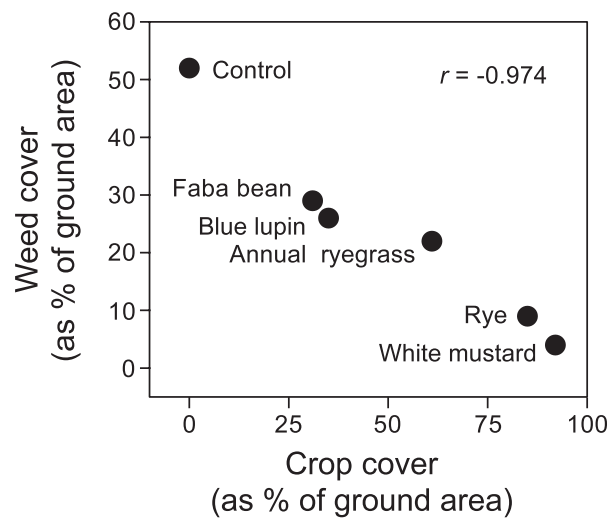

Fig. 1 Weed cover as a function of crop cover in a field experiment conducted in New Zealand with five cover crop treatments and a fallow control. Source: McLenaghen et al. (1996). 
Fig. 2 Weed biomass in solecropped barley and barley intercropped with red clover. Measurements were made from 1988 to 1993 at Stillwater, Maine, at the time of barley harvest in August (Summer, Year 1), in late October of the harvest year (Autumn, Year 1) and in May of the following year (Spring, Year 2). Asterisks indicate significant differences between treatments $(P<0.05)$. Source: M Liebman, unpubl. obs.

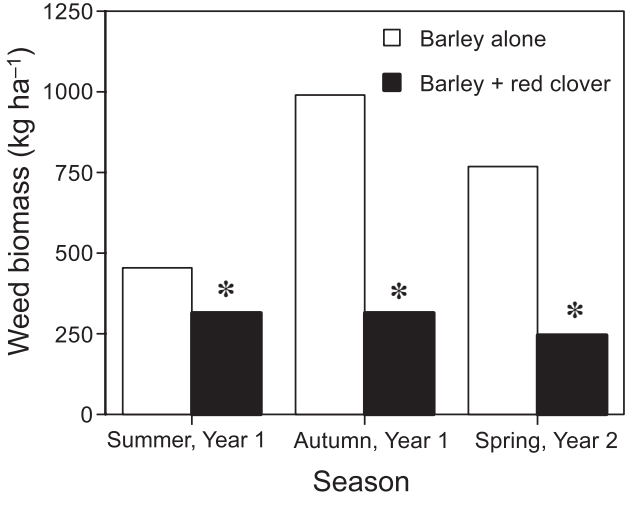

Although intercropping is well-suited to labour-intensive farming systems, certain crop mixtures are compatible with farm machinery. Mixtures of cereals, such as barley (Hordeum vulgare L.), wheat or oats (Avena sativa L.), with forage legumes, such as red clover (Trifolium pratense L.) or lucerne, are common in mechanized temperate farming systems and can be useful for suppressing the growth of perennial cool-season weeds, such as Elytrigia repens (L.) Nevski (Dyke \& Barnard, 1976). Figure 2 shows quantities of weed biomass measured at three dates in an experiment in which barley was sown either alone or simultaneously with red clover. After removal of barley grain with a combine harvester, red clover grew until the field was ploughed the next spring. Red clover reduced weed biomass at barley harvest and suppressed weed growth during the subsequent autumn and spring, when sole-cropped barley plots lay fallow. As discussed later, residues of red clover and other forage legumes that are initially established in intercrop mixtures can serve as important sources of both $\mathrm{N}$ and weed-suppressive chemical compounds.

\section{Soil conditions and the importance of seed mass}

Crop diversification, in addition to changing weed regeneration niches and patterns of resource availability, alters soil physical, chemical and biological properties that affect weeds. Other practices commonly used in LEI systems, notably the use of composts and animal manures, also affect the soil environment. Because weeds (as well as crops) are anchored to one location by their roots and because most dispersal of weed propagules occurs over short distances, local edaphic conditions strongly influence growth and population dynamics. Furthermore, because small advantages in early season seedling growth can translate into large differences in size and light interception ability later in the season, early responses to soil conditions can be critical for determining competitive interactions between weeds and crops.

Managing soils to optimize crop performance and suppress weeds requires (i) identification of differential responses of crop and weed species to edaphic factors and (ii) manipulation of the soil environment to exploit these differences. Mohler (1996) argued that differences in seed mass form the primary biological basis for selectively controlling weeds. We support that argument for reasons detailed in later sections and suggest that seed mass is particularly important for selectively suppressing weeds with crop residues, manures and composts.

Many crops have propagule weights between one and three orders of magnitude greater than those of the weeds with which they compete (Mohler, 1996; Fig. 3). Large seed mass confers an 


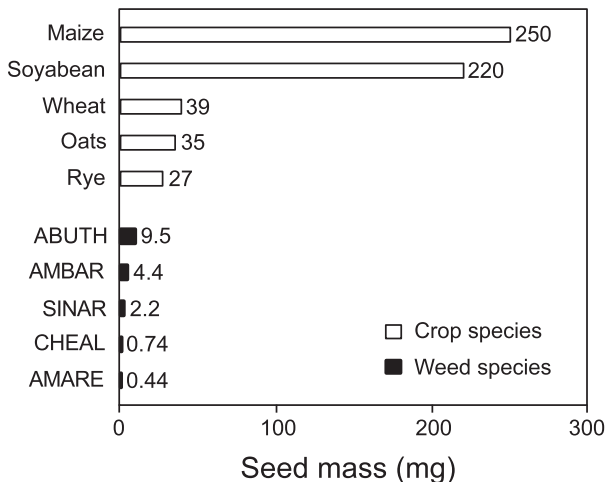

Fig. 3 Seed weights of the five most commonly planted annual agronomic crops in New York state and the five annual weeds most commonly found in those crops. ABUTH: Abutilon theophrasti; AMBAR: Ambrosia artemisiifolia; SINAR: Sinapis arvensis; CHEAL: Chenopodium album; AMARE: Amaranthus retroflexus. Source: Mohler (1996).

initial size advantage to seedlings (Fenner, 1983). Moreover, variations in seed mass are related to the quantity of energy and nutrients stored within seeds, seedling emergence depth (Mohler, 1996) and seedling biomass allocation and physiology (Seibert \& Pearce, 1993). These traits link seed mass differences with differential responses to nutrient deficits and germination and establishment hazards caused by management effects on the soil environment.

Rapid growth fuelled by intensive resource uptake allows small-seeded weeds to overtake slower-growing crops, but results in greater early season dependence by weeds upon external nutrient sources. In a study of three crop and three weed species varying in seed mass, Seibert \& Pearce (1993) found strong negative correlations between seed mass and relative growth rate (RGR) $(r=-0.99 ; P<0.01)$, and between seed mass and specific root length $(r=-0.90$; $P<0.05)$. The small-seeded species in their study, all of which were weeds, combined high RGR with a root system having large absorptive area per unit mass.

Under the high-fertility conditions found in many agricultural ecosystems, weeds can not only maintain a higher RGR, but also concentrate nutrients in their tissues more effectively than crops (DiTomaso, 1995). Grime (1977) suggested, however, that competitive advantages conferred by a high maximal RGR strategy come at the cost of greater growth reductions in stressful environments. A study by Shipley \& Keddy (1988) indicated that species with the highest $\mathrm{RGR}_{\max }$ under optimal nutrient conditions suffered the largest declines in $\mathrm{RGR}_{\text {max }}$ under deficient nutrient conditions. This suggests that farming practices that minimize nutrient availability early in the growing season may leave small-seeded weeds at a distinct disadvantage relative to better provisioned crops. The use of organic nutrient sources may be important in this regard.

Differences in seed reserves also control the depth from which seedlings may emerge successfully. Large-seeded crops tend to emerge from depths of $2.5-5 \mathrm{~cm}$, whereas many weed species tend to emerge from depths of less than $2.5 \mathrm{~cm}$ (Mohler, 1996). Greater emergence depth may mitigate seedling exposure to germination and emergence hazards that operate at or near the soil surface, including phytotoxic crop residues (Weston, 1996), insect herbivores (Hartke et al., 1998) and phytopathogens (Dabney et al., 1996). Proximity to phytotoxic residues and seed coat damage by granivores (Kremer \& Spencer, 1989) may both cause increased pathogenesis in seeds near the soil surface.

We suggest, as an organizing principle, the hypothesis of Westoby et al. (1996) that seedlings arising from heavier seeds are more resistant to nutrient stress, allelopathy, disease and herbivory. We now turn to a discussion of how these factors may be exploited through manipulations of the soil environment. 


\section{Nutrient management and weeds in LEl systems}

Soil fertility is a key component of all farming systems managed with the goal of sustaining or improving yields, and fertilization with synthetic or organic nutrient sources is standard practice in both conventional and LEI systems. Both crop and weed species respond to increases in soil fertility. However, because root and shoot responses to nutrient enrichment often differ among species, fertilizer application can shift the balance of competitive relationships between crops and weeds.

Nitrogen is often the most limiting element for plant growth in agro-ecosystems, and its status in the soil can have strong effects on weed:crop interactions. Studies conducted with synthetic N fertilizers indicate that they can increase both the rate and the total amount of weed germination (Karssen \& Hilhorst, 1992) and may promote weed growth more than crop growth (DiTomaso, 1995). Consequently, $\mathrm{N}$ application can have a neutral or even negative effect on crop yields under weed-infested conditions. For example, Appleby et al. (1976) reported that wheat yields were no higher or slightly reduced by $\mathrm{N}$ application when the crop grew with high densities of Lolium multiflorum Lam. Carlson \& Hill (1985) found that application of $\mathrm{N}$ fertilizer to Avena fatua/spring wheat mixtures increased crop yield only when $A$. fatua density was $<1.6 \%$ of the total weed plus crop density. At high $A$. fatua densities, $\mathrm{N}$ application increased the weed's panicle production by as much as $140 \%$ and decreased wheat yield by as much as $49 \%$ compared with unfertilized treatments.

Other studies have shown, however, that $\mathrm{N}$ fertilizer can improve the competitive status of crops. Tollenaar et al. (1994) found that applying $\mathrm{N}$ to maize/weed mixtures (mostly Amaranthus retroflexus L., Chenopodium album L. and Setaria viridis (L.) Beauv.) increased maize yield and competitive ability and reduced weed biomass. This was particularly evident for maize hybrids selected for greater $\mathrm{N}$ uptake and higher rates of net photosynthesis per unit of leaf N. Similarly, McKenzie (1996) observed that increasing rates of $\mathrm{N}$ fertilizer reduced weed tiller density and relative frequency in perennial ryegrass pastures, an effect attributed to the crop's ability to produce more leaf area and shade weeds more effectively under high-fertility conditions.

Variation in crop and weed responses to soil fertility regimes under experimental conditions indicates the need better to understand interactions between management practices and speciesspecific physiological and morphological characteristics. The timing of nutrient availability relative to crop and weed demands upon nutrient supplies appears to be especially important for determining the outcome of competitive interactions. In cases in which weeds are capable of absorbing nutrients earlier and more rapidly than crops, fertilizer application before or at planting may promote weed germination and growth to the detriment of the crop. Consequently, delayed nutrient application may be a useful strategy for starving weeds during critical initial growth stages and better matching nutrient supply with crop uptake capacity. Alkämper et al. (1979) tested this hypothesis by applying fertilizer at different times to maize, Sinapis arvensis and Chenopodium album grown in pots. Treatments consisted of different NPK rates applied either in a single dose at planting or with one-half the total application at planting plus one-half at maize ear emergence. Delayed fertilizer applications increased crop biomass by as much as $70 \%$ and reduced weed biomass by as much as $50 \%$, compared with early applications of the same total quantities of fertilizer.

Similar results were obtained by Angonin et al. (1996), who conducted a field experiment to test how the timing of $\mathrm{N}$ fertilizer application affected competition between winter wheat and Veronica hederifolia L. Over a wide range of weed densities, $V$. hederifolia biomass was more 
than twice as high when $\mathrm{N}$ fertilizer was applied at the tillering stage of wheat development than when it was applied later at the stem elongation stage. Veronica hederifolia had no effect on wheat $\mathrm{N}$ uptake and yield when fertilizer was applied at stem elongation, whereas it reduced wheat $\mathrm{N}$ uptake and yield when fertilizer was applied at tillering. The investigators noted that the growth, development and potential competitive effect of $V$. hederifolia were concentrated early in the growing season, and that delaying $\mathrm{N}$ application reduced the weed's competitive ability by benefiting the crop more than the weed.

As previously discussed, high initial relative growth rate is negatively correlated with seed mass and seed reserves, so delayed fertilization is likely to be most useful for managing smallseeded weed species in large-seeded crops. One combination of species for which delayed nutrient application does not consistently improve crop yield and reduce weed growth is Bromus tectorum in winter wheat (Anderson, 1991; Ball et al., 1996). Interestingly, the difference in seed mass of those species (B. tectorum: $3 \mathrm{mg}$ seed $^{-1}$, Upadhaya et al., 1986; wheat: $29 \mathrm{mg} \mathrm{seed}^{-1}$, Mohler, 1996 ) is much smaller than the difference in seed mass of species whose growth is decreased by delaying nutrient availability (see Fig. 3 for seed masses of maize, Sinapis arvensis and Chenopodium album).

The potential impacts of delayed nutrient availability on weed and crop performance are particularly relevant to considerations of LEI systems, which place considerable emphasis on using crop residues, composts, manures and other organic materials as nutrient sources. Decomposition of organic materials and subsequent changes in soil nutrient status are affected by a variety of factors, including age and quality (e.g. C:N ratio, lignin and polyphenol contents) of the materials, loading rate, temperature and moisture conditions, soil aeration and $\mathrm{pH}$, tillage and its timing and soil biota (Palm \& Sanchez, 1991; Honeycutt et al., 1993; Dou et al., 1995). Because decay and nutrient transformations require time, soil inorganic nutrient concentrations may increase more slowly after application of organic materials than after an application of synthetic fertilizer at or before planting.

Slower $\mathrm{N}$ release from legume residues than from synthetic fertilizer can be seen in the results of a study conducted by Varco et al. (1993). Using ${ }^{15} \mathrm{~N}$-labelled hairy vetch residue and ${ }^{15} \mathrm{~N}$-labelled ammonium nitrate in a maize field, the investigators found that the percentage of soil inorganic ${ }^{15} \mathrm{~N}$ derived from the fertilizer exceeded that from the vetch residue for 30 days after treatments were applied in 1 year and for 45 days in a second year. These results were consistent with data collected by Westcott \& Mikkelsen (1987), who reported that soil inorganic $\mathrm{N}$ levels in a rice (Oryza sativa L.) field were lower for the first 48 days after incorporation of purple vetch (Vicia spp.), compared with application of ammonium sulphate containing the same amount of $\mathrm{N}$. Other organic materials may also function as slow-release nutrient sources. Although $\mathrm{N}$ and $\mathrm{P}$ can be readily available to plants in raw manure, the availability of those elements from composted manure can be considerably slower. DeLuca \& DeLuca (1997) suggested that only $20 \%$ of the total $\mathrm{N}$ and $60 \%$ of the total $\mathrm{P}$ contained in composted manure would become available to plants in the first year after application to the soil.

Plant $\mathrm{N}$ uptake data also suggest that organic materials can function as slow-release nutrient sources, compared with synthetic fertilizer applied in a single dose at the start of the growing season. In a field experiment, Ladd \& Amato (1986) found that $17 \%$ of the ${ }^{15} \mathrm{~N}$ label in residues of the legume Medicago littoralis Rohde ex. Lois. was taken up by a wheat crop, whereas $62 \%$ of the label remained in the soil organic fraction. In contrast, an average of $47 \%$ of the labelled $\mathrm{N}$ in urea, ammonium sulphate and potassium nitrate fertilizers was taken up by wheat, and only $29 \%$ remained in the soil organic fraction. Similar results were obtained in field experiments with 
legume residues and synthetic fertilizers conducted by Janzen et al. (1990) and Harris et al. (1994).

However, release of nutrients from organic materials is not always a slow process, particularly when soil temperature is warm, periods of abundant moisture alternate with drying periods and the C:N ratio of decomposing materials is relatively low. Luna-Orea et al. (1996) measured nutrient release from two legume cover crops (Desmodium adscendens Desv. and Pueraria phaseoloides (Roxb.) Benth.) in the Bolivian Amazon and reported that $>50 \%$ of the N, P, K and $\mathrm{Mg}$ contained in 12-month-old plants was released within 4 weeks after they were slashed and placed on the soil surface. In an experiment conducted in the north-central USA (Wisconsin), Stute \& Posner (1995) observed that red clover and hairy vetch cover crops released half of their $\mathrm{N}$ within 4 weeks after incorporation and increased soil inorganic $\mathrm{N}$ concentrations to levels similar to those obtained from ammonium nitrate fertilizer applied at $179 \mathrm{~kg} \mathrm{~N} \mathrm{ha}^{-1}$.

The substantial variation observed in patterns of nutrient release from organic materials makes them comparatively more challenging to manage than synthetic fertilizers. However, organic nutrient sources offer better opportunities for long-term improvements in soil quality. Little effort has been directed towards managing nutrient release from organic materials with the goal of suppressing early season weed germination and growth. If patterns of nutrient release from organic materials can be predicted successfully and regulated effectively, it may be possible to satisfy the nutrient requirements of large-seeded crops, while stressing small-seeded weeds early in the growing season, in a manner similar to that achieved with delayed application of synthetic fertilizers. Collaborative research among soil, crop and weed scientists is needed to address these challenges and opportunities.

\section{Biochemical interactions}

In addition to serving as sources of nutrients, crop residues, animal manures and composts also release chemicals that can inhibit or stimulate crop and weed growth. Managing soil organic amendments thus requires knowledge of how their effects on plant growth can be used to the advantage of crops and the disadvantage of weeds.

\section{Crop residue}

The inhibitory effects of allelochemicals derived from crop residues have been studied by many researchers, and exploitation of these effects for weed management has been reviewed by Weston (1996), Kohli et al. (1998) and others. Because leguminous species of forages and cover crops are commonly used in LEI systems for their $\mathrm{N}$ contributions, their potential allelopathic effects on weed species are of particular interest.

Chung \& Miller (1995) found that lucerne residue mixed with sand reduced growth of Chenopodium album, Amaranthus retroflexus, Digitaria sanguinalis (L.) Scop. and Abutilon theophrasti, although it increased growth of Setaria faberi and Bromus secalinus. Aqueous extracts of lucerne reduced germination and seedling growth of all six of the weed species. In a field study, Dyck \& Liebman (1994) observed that incorporation of crimson clover (Trifolium incarnatum L.) into soil reduced C. album emergence rate, density and biomass production, while having negligible effects on sweetcorn emergence and growth. Lehman \& Blum (1997) reported that amending soil held in Petri dishes with crimson clover and subterranean clover (Trifolium subterraneum L.) residues suppressed the emergence of A. retroflexus and Ipomoea hederacea (L.) 
Jacq. However, incorporation of crimson and subterranean clover residues into soil under field conditions was found to increase germination of A. retroflexus, I. hederacea and Sida spinosa L., relative to an unamended control treatment (Blum et al., 1997). The investigators attributed this stimulatory effect to an increased number and quality of germination sites, but suggested that it may also have been related to higher soil nitrate levels in legume-amended plots than in the control.

Allelopathic effects of several non-leguminous cover crops, such as rye (Secale cereale L.) and certain crucifer species, have been studied intensively. Although rye can suppress weeds by reducing light and nutrient availability and altering soil physical conditions, significant weed suppression under field conditions has been attributed to the allelochemicals it releases (Weston, 1996), including $\beta$-phenyllactic acid and $\beta$-hydroxybutyric acid (Shilling et al., 1986) and various benzoxazolinone compounds (Barnes \& Putnam, 1987). Glucosinolate compounds contained within crucifer cover crops can also contribute to weed management (Vaughn \& Boydston, 1997). Boydston \& Hang (1995) found that residues of Brassica napus incorporated into field soil before planting potato reduced weed density by $73-85 \%$ and reduced weed biomass by $50-96 \%$. Al-Khatib et al. (1997) reported that soil incorporation of B. napus residues also reduced weed density and biomass in a pea (Pisum sativum L.) production system.

Three factors appear to make it possible to use allelopathy to suppress weeds but not crops. First, the toxicity of plant residues can decline substantially after several weeks of decomposition (Dabney et al., 1996). Waiting several weeks between residue incorporation and seeding a sensitive crop may increase crop safety, while reducing weed establishment before planting. To prevent subsequent stimulation of weed emergence by secondary tillage, this method may require the foregoing of soil disturbance after residue incorporation. Secondly, ridge-tillage equipment and other specialized machinery can be used to clear allelopathic residues from bands where crops seeds are being sown (Exner et al., 1996). Finally, small-seeded weed and crop species appear to be especially susceptible to allelochemicals, whereas large-seeded species appear to be relatively insensitive (Putnam \& DeFrank, 1983). Transplanting seedlings of small-seeded crops may reduce susceptibility to allelochemicals.

In recent laboratory experiments, we investigated the effect of red clover extracts on the early growth of 28 crop and 13 weed species (M Liebman \& D N Sundberg, unpubl. obs.). Hundredseed weights of the species ranged from $20 \mathrm{mg}$ (for Amaranthus rudis Sauer) to $26250 \mathrm{mg}$ (for maize). Seeds were placed on filter paper in Petri dishes and exposed to a $2 \%$ (wt/wt) aqueous extract of finely ground red clover shoots or distilled water. After incubation for 4 days, radicle length (RL) was measured, and radicle inhibition (RI) was calculated for each species as $\mathrm{RI}=\left(\mathrm{RL}_{\text {water }}-\mathrm{RL}_{\text {extract }}\right) / \mathrm{RL}_{\text {water }} \times 100$. As shown in Fig. 4 , there was a highly significant relationship between seed weight and RI, indicating that small-seeded weeds and crops were most susceptible to phytotoxins extracted from red clover. The results suggest that crop rotations that include red clover or other allelopathic crops may shift weed species composition towards larger-seeded taxa.

Several hypotheses for the mechanism of differential suppression of smaller seeded species by allelopathic compounds released from residues are suggested by the ecological characteristics of seeds and seedlings. As noted earlier, small-seeded species tend to have greater amounts of root length per unit of root mass, and thus proportionally greater amounts of absorptive surface area through which allelochemicals may enter. Differences in stored reserves may also contribute to variation among seedlings in their ability to tolerate or detoxify allelochemical stress agents. If allelochemicals are concentrated near residues placed at the soil surface, large-seeded species that 
Fig. 4 Radicle inhibition (see text for explanation) of 28 crop and 13 crop species after 4 days of exposure in Petri dishes to a $2 \%$ aqueous extract (wt/wt) of finely ground red clover shoots. Distilled water was used as the control. Source: M Liebman \& D N Sundberg, unpubl. obs.

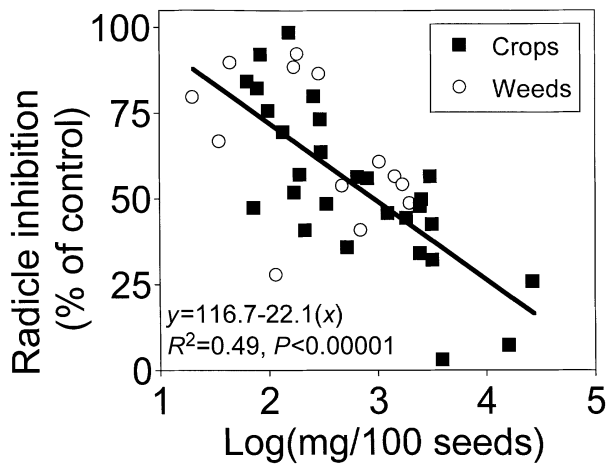

can emerge from deeper in the soil profile may experience lower toxin concentrations than smaller seeded species that tend to germinate higher in the profile.

\section{Manure and compost}

Animal manures and composts made from manure and other materials are common soil amendments in both LEI and conventional farming systems. Manure and plant materials can serve as vectors for weed seeds, but both passive storage of manure and active aerobic composting reduce seed viability for many weed species (Cudney et al., 1992; Tompkins et al., 1998). Death of weed seeds and seedlings in decomposing manure and compost is a function of heat generated by microbial respiration and exposure to a range of biochemicals (Shiralipour \& McConnell, 1991; Grundy et al., 1998). Depending on their age and how they have decomposed, manure and compost may release acetic acid, phenols, ammonia and other organic compounds at concentrations high enough to be phytotoxic (Zucconi et al., 1985; Tiquia \& Tam, 1998; Ozores-Hampton et al., 1999). These compounds can affect weeds before materials are applied to field soil and may affect weed dynamics thereafter.

Although fresh manure and immature composts may serve as sources of phytotoxins, wellaged manures and composts can serve as sources of growth-stimulating substances, such as indole-3-acetic acid and humic and fulvic acids (Chen \& Aviad, 1990; Valdrighi et al., 1996). Beneficial effects of humic substances on plant growth are believed to result from increased membrane permeability, greater nutrient uptake, enhanced protein synthesis and photosynthesis, changes in enzyme activity and effects similar to those resulting from the application of plant growth regulators (Chen \& Aviad, 1990). It remains to be learned whether growth-stimulating substances from manures and composts affect weeds and crops differentially on the basis of seed mass or other factors.

\section{Pathogens and insect pests of weeds}

Plant pathologists frequently invoke a 'disease triangle' to describe the interaction between a pathogen, its host and the environment (Agrios, 1988). The classical approach to weed biocontrol with plant pathogens has often focused on two legs of the triangle, pathogen and host, but has paid relatively little attention to the management of environmental conditions (Hasan \& Ayres, 1990). However, the development of weed-suppressive soils in LEI systems requires that the disease triangle be approached as a whole, with the soil environment being manipulated to 
(i) enhance the activity and detrimental effects of indigenous pathogens on weed seeds and seedlings; and (ii) increase the susceptibility of weed hosts to pathogens (Kennedy \& Kremer, 1996; Gallandt et al., 1999).

Organic amendments may have stimulatory or inhibitory effects on pathogen activity, depending on factors that are not well understood, but which may include the degree of decomposition that the organic matter has undergone. Fresh plant residues appear to stimulate the germination of fungal spores, i.e. break fungistasis, by increasing the availability of substrates necessary for fungal growth (Toussoun \& Patrick, 1963). On the other hand, highly decomposed organic amendments may increase fungistasis through stimulation of antagonistic organisms (Craft \& Nelson, 1996) or reduced substrate availability (Mandelbaum \& Hadar, 1990).

Regulating host susceptibility with organic amendments is a promising avenue for weed suppression through soil management. Studies of the influence of cover crop residues on seedling disease suggest that phytotoxic compounds contained in fresh plant residues, especially legumes, can dramatically increase pathogenesis by fungal root rots (Toussoun \& Patrick, 1963; Dabney et al., 1996). Phytotoxins may also be responsible for the promotion of fungal attack of weed seeds by cover crop residues. Placement of cover crop residues near the soil surface through reduced tillage increased the abundance of Alternaria alternata (Fr.) and Epicoccum purpurascens Eherenb. ex Schlecht, and promoted colonization of Setaria spp. caryopses by the fungi (Pitty et al., 1987).

Several possibilities exist for protecting crops in LEI systems from pathogens used for weed suppression. Delaying crop planting by 2-4 weeks after cover crop incorporation can reduce problems with crop stand establishment following cover crops (Dabney et al., 1996). Clearing residues from the crop row can also improve crop establishment in high-residue systems (Kaspar et al., 1990). This practice may reduce the risk of pathogenic attack on crop seeds and shorten the interval between cover crop incorporation and crop planting to as little as 1 week (Dabney et al., 1996). Shortened intervals between residue incorporation and crop planting could increase planting date flexibility, facilitating the planting of crop species when soil temperatures favour maximal germination velocity, critical to preventing seedling attack by fungi (Leach, 1947).

Because placement of organic residues at the soil surface can increase fungal attack of weed seeds (Pitty et al., 1987) and seedlings (Dabney et al., 1996), shallow incorporation of cover crop residues, combined with a slightly deeper planting depth for the crop seed, might reduce the risks of crop seed infection by active fungal pathogens. Crops might also be protected through the use of disease-resistant crop cultivars, which are especially important in LEI systems as alternatives to fungicidal seed treatments (Gallandt et al., 1999). Another possibility for conferring resistance upon a susceptible crop is to inoculate seed with beneficial rhizobacteria (Schippers et al., 1987). Finally, seed mass differences between crop and weed species (Mohler, 1996) may provide a basic level of selectivity. Our search of the scientific literature revealed no studies that directly examined seed and seedling susceptibility to pathogenic attack in relation to seed mass; this may be an important line of investigation for an integrative approach to weed biocontrol.

Depending upon farming practices and environmental conditions, insects can also play an important role in weed seed and seedling mortality (Brust \& House, 1988; Hartke et al., 1998). In LEI systems, increased numbers and activity of granivorous insects can result from reduced pesticide inputs (Brust \& House, 1988) and the creation of a more suitable habitat through crop rotation (Zhang et al., 1998) and increased surface residues (Brust \& House, 1988). Insect seed feeders can greatly enhance fungal attack by piercing the seed coat. Up to $98 \%$ of Abutilon theophrasti seeds were infected by Fusarium spp. when gaps were created in the weed's seed coat 
by the scentless plant bug (Niesthrea louisianica Sailer); in contrast, only $8 \%$ of $A$. theophrasti seeds protected from insect attack were infected (Kremer \& Spencer, 1989). In a feeding preference study of weed seeds in the northern Maine potato (Solanum tuberosum L.) agroecosystem (Hartke et al., 1998), biomass and number of seeds consumed were inversely proportional to seed mass for all larval instars of the carabid beetle (Harpalus rufipes De Geer). Synergistic interactions between granivores and pathogens may thus have their greatest impact on the seeds of small-seeded weed species.

\section{Weed dynamics in two experimental LEI systems}

\section{Sinapis arvensis in sweetcorn}

Previous work by Dyck et al. (1995) demonstrated that soil-incorporated residues of a crimson clover cover crop could suppress Chenopodium album growth in pure stand and reduce its ability to interfere with sweetcorn (Zea mays L.). Non-N residue-mediated effects, such as phytotoxicity, were implicated as the primary mode of suppression, but delayed $\mathrm{N}$ release from the organic $\mathrm{N}$ source compared with ammonium nitrate fertilizer applied at planting was also identified as a possible factor in C. album suppression.

To determine whether weed suppression by an organic $\mathrm{N}$ source is caused mainly by delayed $\mathrm{N}$ availability or non- $\mathrm{N}$ residue-mediated effects, a field experiment was conducted in 1997 and 1998 (A S Davis \& M Liebman, unpubl. obs.). Sweetcorn (cv. 'Clockwork') was grown with or without interference from Sinapis arvensis in a 2-year rotation with spring wheat grown in pure stand or as an intercrop with red clover. Four soil management treatments were compared. In the 'Organic' treatment, $\mathrm{N}$ sources consisted of wheat stubble and red clover residue supplemented with compost to achieve a total predicted $\mathrm{N}$ fertilizer replacement value of $110 \mathrm{~kg} \mathrm{~N} \mathrm{ha}^{-1}$ (Fox \& Piekielek, 1988; DeLuca \& DeLuca, 1997). Organic N sources were incorporated into the soil with a disc harrow and PTO-powered rotary cultivator 2 weeks before planting sweetcorn. In the 'Early' synthetic $\mathrm{N}$ treatment, sweetcorn plots were fertilized with $110 \mathrm{~kg} \mathrm{~N} \mathrm{ha}^{-1}$ as ammonium nitrate banded next to the crop row at planting. In the 'Split' synthetic $\mathrm{N}$ treatment, $20 \mathrm{~kg} \mathrm{~N} \mathrm{ha}^{-1}$ ammonium nitrate was applied at planting and $90 \mathrm{~kg} \mathrm{~N} \mathrm{ha}^{-1}$ was applied when the sweetcorn plants reached $20-30 \mathrm{~cm}$ in height. Organic, Early and Split treatments were compared with the 'Control', which received no fertilizer, red clover residue or compost.

Analysis of soil cores taken to a 30-cm depth in 1998 revealed that soil $\mathrm{NO}_{3}-\mathrm{N}$ concentration at 9 and 29 days after planting (DAP) was lower in the Organic and Split treatments than in the Early treatment. Sweetcorn N uptake at 56 DAP in 1997 was lower in the Organic and Split treatments than in the Early treatment, implying that soil $\mathrm{N}$ levels before this date also followed the same pattern. These results suggest that the Organic $\mathrm{N}$ treatment acted as a slow-release $\mathrm{N}$ source.

In 1997, sweetcorn above-ground biomass and marketable ear weight did not differ among the Organic, Early and Split N treatments. In 1998, sweetcorn above-ground biomass was unaffected by $\mathrm{N}$ source, but marketable ear weight was $27 \%$ greater in Organic than in Early or Split treatments. The difference between sweetcorn yields in weed-free and weedy treatments was $50 \%$ less in the Organic treatment than in the Early and Split treatments, indicating that interference by $S$. arvensis was also less in the Organic treatment. In 1998, the season-long average of Sinapis arvensis shoot biomass was $13 \%$ less in the Organic treatment than in the Early treatment 


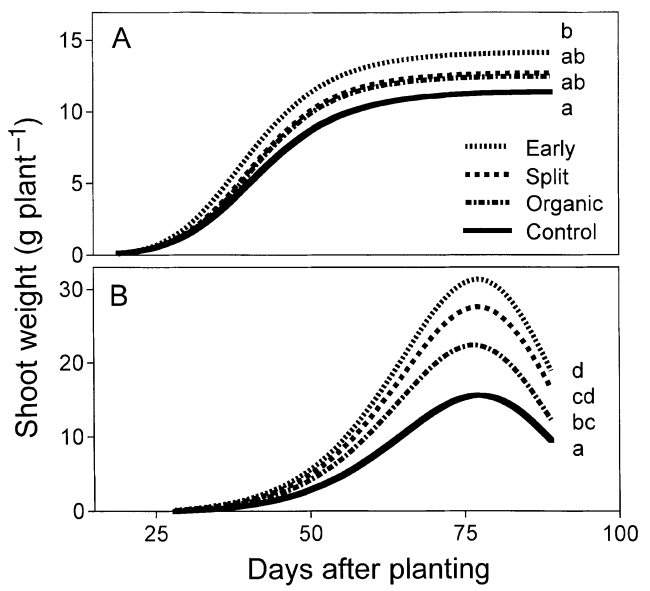

Fig. 5 Shoot growth of Sinapis arvensis grown with sweetcorn cv. 'Clockwork' under N fertility management regimes varying in timing and source of $\mathrm{N}$ in 1997 (A) and 1998 (B). Early: $110 \mathrm{~kg} \mathrm{~N}$ ha ${ }^{-1}$ applied as $\mathrm{NH}_{4} \mathrm{NO}_{3}$ at planting; Split: $20 \mathrm{~kg} \mathrm{~N}^{-1}$ applied as $\mathrm{NH}_{4} \mathrm{NO}_{3}$ at planting, followed by $90 \mathrm{~kg} \mathrm{~N}$ ha ${ }^{-1}$ applied when the sweetcorn plants reached $20-30 \mathrm{~cm}$ in height; Organic: $110 \mathrm{~kg} \mathrm{~N}^{-1}$ total $\mathrm{N}$ fertilizer replacement value from a red clover/winter wheat intercrop plus composted dairy cattle manure and timber slash (forest bark mulch); Control: no $\mathrm{N}$ fertilizer, clover residue or composted manure added. Curves followed by different lower case letters are significantly different $(P<0.05)$, as indicated by residual sum of squares analysis (Lindquist et al., 1996). Source: A S Davis \& M Liebman, unpubl. obs.

(Fig. 5b); a similar trend was evident in 1997 (Fig. 5a). Greater suppression of S. arvensis by the Organic treatment in 1998 appeared to be linked to twice as much red clover biomass production in 1998 as in 1997.

Similarities in soil $\mathrm{N}$ and effects on $S$. arvensis shoot weight between the Organic and Split treatments (Fig. 5a and b) suggest that the timing of $\mathrm{N}$ availability affected weed dynamics. However, the much stronger effect of the Organic treatment on sweetcorn yield suggests that non- $\mathrm{N}$ residue-mediated effects primarily drove the crop:weed interaction. Further evidence comes from bioassays performed by A Conklin (unpubl. obs.), who examined the effect of soils from the Organic and Early treatments on disease incidence in S. arvensis seedlings. In 1997, Pythium and Rhizoctonia spp. infected up to $82 \%$ of $S$. arvensis seedlings incubated in soil from the Organic treatment compared with $<35 \%$ of seedlings in the Early treatment; in 1998 , the fungi infected up to $42 \%$ of the $S$. arvensis seedlings in the Organic treatment but $<13 \%$ in the Early treatment. Weed-suppressive effects of soil collected from the Organic treatment were most severe for the first 2 weeks after cover crop and compost incorporation.

\section{Chenopodium album and other weeds in potato}

A second experiment investigated weed dynamics in contrasting soil, crop and pest management systems used for potato production in northern Maine (Gallandt et al., 1998a,b). The experiment was established in 1991 and included two potato cultivars, 'Superior' and 'Atlantic.' The latter cultivar is more disease tolerant than the former and is better suited to LEI systems. Management practices and data from 'Atlantic' potato plots in 1994-98 will be discussed here.

Two crop rotation/soil amendment treatments were used in the experiment. In the 'unamended' system, potato was grown in alternate years with barley harvested for grain, and 
treated with high rates of synthetic fertilizers. In the 'amended' system, potato was grown in alternate years with an unharvested green manure mixture (oats + field pea + hairy vetch), and treated with beef cattle manure (45 $\mathrm{Mg} \mathrm{ha}^{-1}$, fresh wt basis), compost made from beef cattle manure and cull potatoes (22 $\mathrm{Mg} \mathrm{ha}^{-1}$, fresh wt basis) and reduced rates of synthetic fertilizers (65-125 kg N ha ${ }^{-1} ; 0-80 \mathrm{~kg} \mathrm{P}_{2} \mathrm{O}_{5} \mathrm{ha}^{-1} ; 0-165 \mathrm{~kg} \mathrm{~K}_{2} \mathrm{O} \mathrm{ha}^{-1}$ ). The unamended system represented standard crop rotation and fertilization practices in the region. The amended system was used to investigate the impacts of rapidly changing soil physical, chemical and biological properties through increased reliance on organic nutrient sources. Soil and plant tissues were monitored, and fertilization practices were adjusted to ensure that nutrient availability to potato crops was equal in both systems.

Included within the experiment was a mechanical weed management treatment in which weeds were suppressed with pre- and post-emergence spring-tine harrowing, inter-row cultivation and ridging, but no herbicides. Weed biomass in potato crops managed with this treatment was measured during the latter part of the crop production season each year, and potato tuber yields were determined at crop maturity.

The weed community was dominated by Chenopodium album and several cruciferous species (Brassica rapa, Sinapis arvensis and Raphanus raphanistrum L.), and was strongly influenced by crop rotation and soil amendment practices. From 1994 until 1998, 73\% less weed biomass was produced in the amended treatment than in the unamended treatment (Fig. 6a). Year-to-year variation in weed biomass was also markedly lower in the amended potato crop system. Gallandt et al. (1998a) attributed the reductions in weed biomass in the amended system to greater competitive ability of the potato crop. Potato plants in the amended system tended to produce more leaf area and suffer less yield loss to weed competition (Gallandt et al., 1998a) and, over the

Fig. 6 Weed biomass (A) and potato (cv. 'Atlantic') tuber production (B) as affected by crop rotation and soil amendment treatments in an experiment conducted in Presque Isle, Maine, 1994-98. Weeds were controlled mechanically, without herbicide applications. US no. 1 yield represents undiseased, defect-free tubers from 4.8 to $10.2 \mathrm{~cm}$ in diameter. 'Unamended' potatoes were grown in alternate years with barley and treated with high rates of synthetic fertilizers, whereas 'amended' potatoes were grown in alternate years with a green manure mixture (oats + field pea + hairy vetch) and treated with beef cattle manure, compost made from beef cattle manure and cull potatoes, and low rates of synthetic fertilizers. See text for fertilizer and organic amendment rates. Sources: Gallandt et al. (1998a); M Liebman \& G A Porter, unpubl. obs.

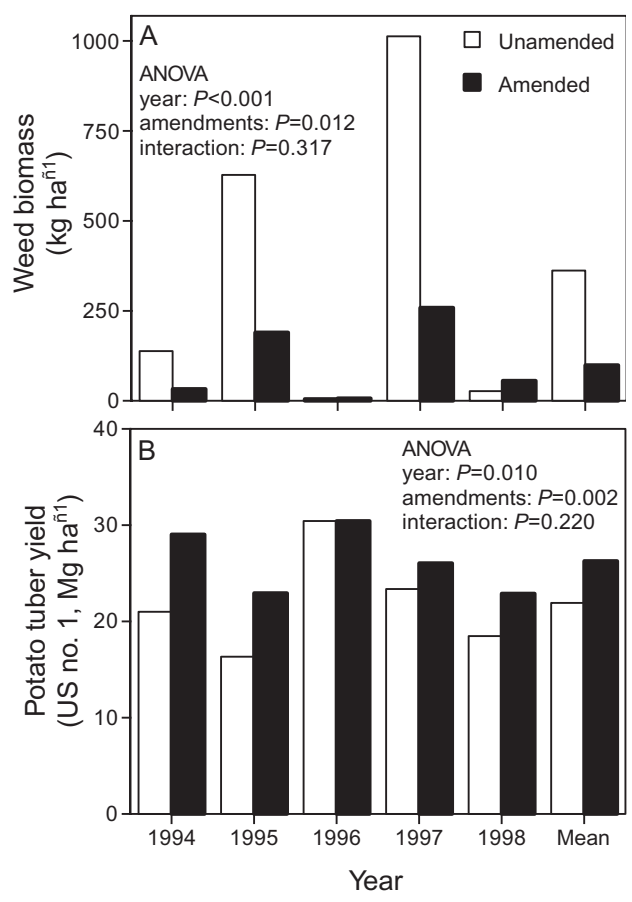


period 1994-98, had a 20\% higher tuber yield (Fig. 6b). Although the biochemical, physical and ecological mechanisms contributing to these results were not elucidated, the results indicate that crop rotation and organic soil amendments can greatly improve mechanical weed control. The results also emphasize the importance of looking at weed management within a broader agroecosystem context.

\section{Future directions}

Low-external-input farming systems require diverse crops and regular applications of organic amendments to maintain or improve soil quality and productivity. Both crop diversity and organic amendments can also contribute to weed management by increasing weed seed and seedling mortality; delaying weed seedling emergence relative to crop emergence; reducing resource capture by weeds; lessening weed seed and vegetative propagule production; and diminishing variation in weed growth between years. Our review of how crop diversification and soil management practices affect weed ecology and performance indicates that differences in seed mass may constitute an important basis for selectively suppressing weeds while protecting crops from harm.

To integrate soil, crop and weed management effectively, much work remains to be done by scientists spanning a broad range of disciplines. We offer, in closing, three interdisciplinary research questions that seem to be especially important for improving weed management in both LEI and conventional farming systems. First, what ecological processes relevant to weed population dynamics and weed:crop interference are affected by farming practices that protect and improve soil health? Secondly, what are the biological ramifications of seed mass, especially with reference to resource capture and tolerance of hazards encountered during germination and establishment? Finally, how can we increase the precision with which we manipulate the soil environment through management of crop diversity and soil organic amendments? Answers to these questions will not be easy to obtain, but are critical, in our view, for developing sustainable farming systems.

\section{Acknowledgements}

We thank C Berube, A Conklin, P N Dixon, M S Erich, E R Gallandt, C L Mohler, G A Porter and S D Ullrich for sharing data and insights with us. This is Journal Paper No. J-18484 of the Iowa Agriculture and Home Economics Experiment Station, Ames, IA, supported by Project no. 3532 of the Hatch Act and State of Iowa.

\section{References}

Abraham CT \& Singh SP (1984) Weed management in sorghum-legume intercropping systems. Journal of Agricultural Science, Cambridge 103, 103-115.

Agrios GN (1988) Plant Pathology. Academic Press, San Diego, USA.

Alkämper J, Pessios E \& Long DV (1979) Einfluss der düngung auf die entwicklung und nährstoffaufnahme verschiedener unkräuter in mais. In: Proceedings 3rd European Weed Research Society Symposium, Mainz, Germany, 181-192.

Al-Khatib K, Libbey C \& Boydston R (1997) Weed suppression with Brassica green manure crops in green pea. Weed Science 45, 439-445.

(C) Blackwell Science Ltd Weed Research 2000 40, 27-47 
ANDERson RL (1991) Timing of nitrogen application affects downy brome (Bromus tectorum) growth in winter wheat. Weed Technology 5, 582-585.

Angonin C, Caussanel JP \& Meynard JM (1996) Competition between winter wheat and Veronica hederifolia: influence of weed density and the amount and timing of nitrogen application. Weed Research 36, 175-187.

Appleby AP, Olson PD \& Colbert DR (1976) Winter wheat yield reduction from interference by Italian ryegrass. Agronomy Journal 68, 463-466.

Ball DA, Wysocki DJ \& Chastain TG (1996) Nitrogen application timing effects on downy brome (Bromus tectorum) and winter wheat (Triticum aestivum) growth and yield. Weed Technology 10, 305-310.

Barnes JP \& Putnam AR (1987) Role of benzoxazinones in allelopathy by rye (Secale cereale L.). Journal of Chemical Ecology 13, 889-906.

Benbrook CM (1996) Pest Management at the Crossroads. Consumers Union, Yonkers, NY, USA.

BlACKSHAw RE (1994) Rotation affects downy brome (Bromus tectorum) in winter wheat (Triticum aestivum). Weed Technology 8, 728-732.

Blum U, King LD, Gerig TM, Lehman ME \& Worsham AD (1997) Effects of clover and small grain cover crops and tillage techniques on seedling emergence of some dicotyledonous weed species. American Journal of Alternative Agriculture 12, 146-161.

Bowman G, ed.. (1998) Steel in the Fields - A Farmer's Guide to Weed Management Tools. Sustainable Agriculture Network, National Agricultural Library, Beltsville, MD, USA.

Bowman G, Shirley C \& Cramer C (1998) Managing Cover Crops Profitably. Sustainable Agriculture Network, National Agricultural Library, Beltsville, MD, USA.

Boydston R \& HANG A (1995) Rapeseed (Brassica napus) green manure crop suppresses weeds in potato (Solanum tuberosum). Weed Technology 9, 669-675.

BRUST GE \& House GJ (1988) Weed seed destruction by arthropods and rodents in low-input soybean agroecosystems. American Journal of Alternative Agriculture 3, 19-25.

CARLSON HL \& Hill JE (1985) Wild oat (Avena fatua) competition with spring wheat: effects of nitrogen fertilization. Weed Science 34, 29-33.

Chen Y \& Aviad T (1990) Effects of humic substances on plant growth. In: Humic Substances in Soil and Crop Sciences: Selected Readings, (eds P MacCarthy, CE Clapp, RL Malcolm \& PR Bloom), 161-186. American Society of Agronomy and Soil Science Society of America, Madison, WI, USA.

Chung IM \& Miller DA (1995) Natural herbicide potential of alfalfa residue on selected weed species. Agronomy Journal 87, 920-925.

Covarelli G \& Tei F (1988) Effet de la rotation culturale sur la flore adventice du mais. In: VIIIeme Colloque International Sur la Biologie, l'Ecologie et la Systematique Des Mauvaises Herbes, Vol. 2, 477-484. Comite Francais de Lutte Contre les Mauvaises Herbes, Paris, France and European Weed Research Society, Leverkusen, Germany.

Craft CM \& Nelson EB (1996) Microbial properties of composts that suppress damping-off and root rot of creeping bentgrass caused by Pythium graminicola. Applied and Environmental Microbiology 62, 1550-1557.

Cudney DW, Wright SD, Shultz TA \& Reints JS (1992) Weed seed in dairy manure depends on collection site. California Agriculture 46 (3), 31-32.

Dabney SM, Schreiber JD, Rothrock CS \& Johnson JR (1996) Cover crops affect sorghum seedling growth. Agronomy Journal 88, 961-970.

DeLuca TH \& DeLuca DK (1997) Composting for feedlot manure management and soil quality. Journal of Production Agriculture 10, 235-241.

DiTomaso JM (1995) Approaches for improving crop competitiveness through manipulation of fertilization strategies. Weed Science 43, 491-497.

Dou Z, Fox RH \& Tотн JD (1995) Seasonal soil nitrate dynamics in corn as affected by tillage and nitrogen source. Soil Science Society of America Journal 59, 858-864.

Dowling PM \& Wong PTW (1993) Influence of preseason weed management and in-crop treatments on two successive wheat crops. 1. Weed seedling numbers and wheat grain yield. Australian Journal of Experimental Agriculture 33, 167-172. 
Dyck E \& Liebman M (1994) Soil fertility management as a factor in weed control: the effect of crimson clover residue, synthetic nitrogen fertilizer, and their interaction on emergence and early growth of lambsquarters and sweet corn. Plant and Soil 167, 227-237.

Dyck E, Liebman M \& ERich MS (1995) Crop-weed interference as influenced by a leguminous or synthetic fertilizer nitrogen source: I. Doublecropping experiments with crimson clover, sweet corn, and lambsquarters. Agriculture, Ecosystems and the Environment 56, 93-108.

DYKe GV \& BARNARD AJ (1976) Suppression of couchgrass by Italian ryegrass and broad red clover undersown in barley and field beans. Journal of Agricultural Science, Cambridge 87, 123-126.

EGLEy GH \& Williams RD (1991) Emergence periodicity of six summer annual weed species. Weed Science 39, 595-600.

Entz MH, Bullied WJ \& Katepa-Mupondwa F (1995) Rotational benefits of forage crops in Canadian prairie cropping systems. Journal of Production Agriculture 8, 521-529.

Exner DN, Thompson RL \& Thompson SN (1996) Practical experience and on-farm research with weed management in an Iowa ridge tillage-based system. Journal of Production Agriculture 9, 496-500.

FENNER M (1983) Relationships between seed weight, ash content and seedling growth in twenty-four species of compositae. New Phytologist 95, 697-706.

Forcella F, Wilson RG, Dekker J et al. (1997) Weed seed bank emergence across the Corn Belt. Weed Science 45, 67-76.

Fox RH \& Piekielek WP (1988) Fertilizer N equivalence of alfalfa, birdsfoot trefoil, and red clover for succeeding corn crops. Journal of Production Agriculture 1, 313-317.

Gallandt ER, Liebman M, Corson S, Porter GA \& Ullrich SD (1998a) Effects of pest and soil management systems on weed dynamics in potato. Weed Science 46, 238-248.

Gallandt ER, Liebman M \& Huggins DR (1999) Improving soil quality: implications for weed management. Journal of Crop Production 2, 95-121.

Gallandt ER, Mallory EB, Alford AR et al. (1998b) Comparison of alternative pest and soil management strategies for Maine potato production systems. American Journal of Alternative Agriculture 13, 146-161.

GeIER B (1998) The organic market - opportunities and challenges. ILEIA Newsletter 14 (4), 6-7.

GRIME JP (1977) Evidence for the existence of three primary strategies in plants and its relevance to ecological and evolutionary theory. The American Naturalist 111, 1169-1193.

GrubB PJ (1977) The maintenance of species richness in plant communities: the importance of the regeneration niche. Biological Reviews 52, 107-145.

Grundy AC, Green JM \& Lennartsson M (1998) The effect of temperature on the viability of weed seeds in compost. Compost Science and Utilization 6 (3), 26-33.

Harris GH, Hesterman OB, Paul EA, Peters SE \& Janke RR (1994) Fate of legume and fertilizer nitrogen-15 in a long-term cropping systems experiment. Agronomy Journal 86, 910-915.

Hartke A, Drummond FA \& Liebman M (1998) Seed feeding, seed caching, and burrowing behaviors of Harpalus rufipes De Geer larvae (Coleoptera: Carabidae) in the Maine potato agroecosystem. Biological Control 13, 91-100.

Hasan S \& Ayres PG (1990) The control of weeds through fungi: principles and prospects. New Phytologist 115, 201-222.

Honeycutt CW, Potaro LJ, Avila KL \& Halteman WA (1993) Residue quality, loading rate, and soil temperature relations with hairy vetch (Vicia villosa) residue carbon, nitrogen, and phosphorus mineralization. Biological Agriculture and Horticulture 9, 181-199.

Janzen HH, Bole JB, Biebderbeck VO \& Slinkard AE (1990) Fate of N applied as green manure or ammonium sulfate fertilizer to soil subsequently cropped with spring wheat in three sites in western Canada. Canadian Journal of Soil Science 70, 313-323.

KARSSEN CM \& Hilhorst HWM (1992) Effect of chemical environment on seed germination. In: Seeds: the Ecology of Regeneration in Plant Communities (ed. M. Fenner), 327-348. CAB International, Wallingford, UK.

Kaspar TC, Erbach DC \& CRuse RM (1990) Corn response to seed-row residue removal. Soil Science Society of America Journal 54, 1112-1117. 
Kennedy AC \& Kremer RJ (1996) Microorganisms in weed control strategies. Journal of Production Agriculture 9, 480-485.

Kohli RK, BAtish D \& Singh HP (1998) Allelopathy and its implications in agroecosystems. Journal of Crop Production 1, 169-202.

Kremer RJ \& SPencer NR (1989) Interaction of insects, fungi and burial on velvetleaf (Abutilon theophrasti) seed viability. Weed Technology 3, 322-328.

LADD JN \& Aмато M (1986) The fate of nitrogen from legume and fertilizer sources in soils successively cropped with wheat under field conditions. Soil Biology and Biochemistry 18, 417-425.

LEACH LD (1947) Growth rates of host and pathogen as factors determining the severity of pre-emergence damping-off. Journal of Agricultural Research 75, 161-177.

Lehman ME \& Blum U (1997) Cover crop debris effects on weed emergence as modified by environmental factors. Allelopathy Journal 4, 69-88.

LiEBMAN M \& DyCK E (1993) Crop rotation and intercropping strategies for weed management. Ecological Applications 3, 92-122.

Liebman M \& Gallandt ER (1997) Many little hammers: ecological management of crop-weed interactions. In: Ecology in Agriculture (ed. LE Jackson), 291-343. Academic Press, San Diego, CA, USA.

Liebman M \& Ohno T (1998) Crop rotation and legume residue effects on weed emergence and growth: implications for weed management. In: Integrated Weed and Soil Management (eds JL Hatfield,

DD Buhler \& BA Stewart), 181-221. Ann Arbor Press, Chelsea, MI, USA.

Lin BH, Padgitt M, Bull L, Delvo H, Shank D \& Taylor H (1995) Pesticide and Fertilizer Use and Trends in US Agriculture. Agricultural Economic Report No. 717. Economic Research Service, US Department of Agriculture, Washington, DC, USA.

Lindquist JL, Mortensen DA, Clay SA et al. (1996) Stability of corn (Zea mays)-velvetleaf (Abutilon theophrasti) relationships. Weed Science 44, 309-313.

Lueschen WE, Andersen RN, Hoverstad TR \& Kanne BK (1993) Seventeen years of cropping systems and tillage affect velvetleaf (Abutilon theophrasti) seed longevity. Weed Science 41, 82-86.

Luna-Orea P, Wagger MG \& Gumpertz ML (1996) Decomposition and nutrient release dynamics of two tropical legume cover crops. Agronomy Journal 88, 758-764.

MCKenZIE FR (1996) Influence of applied nitrogen on weed invasion of Lolium perenne pastures in a subtropical environment. Australian Journal of Experimental Agriculture 36, 657-660.

McLenaghen RD, Cameron KC, Lampkin NH, Daly ML \& Deo B (1996) Nitrate leaching from ploughed pasture and the effectiveness of winter catch crops in reducing leaching losses. New Zealand Journal of Agricultural Research 39, 413-420.

Mandelbaum R \& Hadar Y (1990) Effects of available carbon source on microbial activity and suppression of Pythium aphanidermatum in compost and peat container media. Phytopathology 80, 794-804.

Mohler CL (1993) A model of the effects of tillage on emergence of weed seedlings. Ecological Applications 3, 53-73.

Mohler CL (1996) Ecological bases for the cultural control of weeds. Journal of Production Agriculture 9, 468-474.

Mohler CL, Frisch JC \& Mt. Pleasant J (1997) Evaluation of mechanical weed management programs for corn (Zea mays). Weed Technology 11, 123-31.

Norris RF \& Ayres D (1991) Cutting interval and irrigation timing in alfalfa: yellow foxtail invasion and economic analysis. Agronomy Journal 83, 552-558.

Organic Farming Research Foundation (OFRF) (1998) Third Biennial National Organic Farmers' Survey. OFRF, Santa Cruz, CA, USA.

Ozores-Hampton M, Stoffella PJ, Bewick TA, Cantliffe DJ \& Obreza TA (1999) Effect of age of composted MSW and biosolids on weed seed germination. Compost Science and Utilization 7, 51-57.

Palm CA \& SAnchez PA (1991) Nitrogen release from the leaves of some tropical legumes as affected by their lignin and polyphenolic contents. Soil Biology and Biochemistry 23, 83-88.

Pitty A, Staniforth DW \& Tiffany LH (1987) Fungi associated with caryopses of Setaria species from field-harvested seeds and from soil under two tillage systems. Weed Science 35, 319-323. 
Pons TL (1992) Seed responses to light. In: Seeds: the Ecology of Regeneration in Plant Communities (ed. M Fenner), 259-284. CAB International, Wallingford, UK.

Popay AI, Cox TI, Ingle A \& Kerr R (1995) Seasonal emergence of weeds in cultivated soil in New Zealand. Weed Research 35, 429-436.

Putnam AR \& Defrank J (1983) Use of phytotoxic plant residues for selective weed control. Crop Protection 2, 173-181.

Risser PG (1969) Competitive relationships among herbaceous grassland plants. Botanical Review 35, 251-284.

Roberts HA \& FeAst PM (1973) Emergence and longevity of seeds of annual weeds in cultivated and undisturbed soil. Journal of Applied Ecology 10, 133-143.

SCHIPPERs B, BAKKer AW \& BAKER PAHM (1987) Interactions of deleterious and beneficial rhizobacteria. Annual Reviews of Phytopathology 25, 339-358.

SCHREIBER MM (1992) Influence of tillage, crop rotation, and weed management on giant foxtail (Setaria faberi) population dynamics and corn yield. Weed Science 40, 645-653.

Seibert AC \& Pearce RB (1993) Growth analysis of weed and crop species with reference to seed weight. Weed Science 41, 52-56.

Shilling DG, Jones LA, Worsham AD, Parker CE \& Wilson RF (1986) Isolation and identification of some phytotoxic compounds from aqueous extracts of rye (Secale cereale L.). Journal of Agricultural and Food Chemistry 34, 633-638.

Shipley B \& KedDy PA (1988) The relationship between relative growth rate and sensitivity to nutrient stress in twenty-eight species of emergent macrophytes. Journal of Ecology 76, 1101-1110.

Shiralipour A \& McConnell DB (1991) Effects of compost heat and phytotoxins on germination of certain Florida weed seeds. Soil and Crop Science Society of Florida Proceedings 50, 154-157.

Stute JK \& Posner JL (1995) Synchrony between legume nitrogen release and corn demand in the Upper Midwest. Agronomy Journal 87, 1063-1069.

Teasdale JR (1998) Cover crops, smother plants, and weed management. In: Integrated Weed and Soil Management (eds JL Hatfield, DD Buhler \& BA Stewart), 247-270. Ann Arbor Press, Chelsea, MI, USA.

Teasdale JR \& Daughtry CST (1993) Weed suppression by live and desiccated hairy vetch (Vicia villosa). Weed Science 41, 207-212.

Thurston HD (1997) Slash/Mulch Systems: Sustainable Methods for Tropical Agriculture. Westview Press, Boulder, CO, USA.

TiQuiA SM \& TAM NFY (1998) Elimination of phytotoxicity during co-composting of spent pig-manure sawdust litter and pig sludge. Bioresource Technology 65, 43-49.

Tollenaar M, Nissanka SP, Aguilera A, Weise SF \& Swanton CJ (1994) Effect of weed interference and soil nitrogen on four maize hybrids. Agronomy Journal 86, 596-601.

Tompkins DK, Chaw D \& Abiola AT (1998) Effect of windrow composting on weed seed germination and viability. Compost Science and Utilization 6 (1), 30-34.

Toussoun TA \& PATRick ZA (1963) Effect of phytotoxic substances from decomposing plant residues on root rot of bean. Phytopathology 53, 265-269.

Upadhaya MK, Turkington R \& McIlvride D (1986) The biology of Canadian weeds. 75. Bromus tectorum L. Canadian Journal of Plant Science 66, 689-709.

Valdrighi MM, Pera A, Agnolucci M, Frassinetti S, Lunardi D \& Vallini G (1996) Effects of compost-derived humic acids on vegetable biomass production and microbial growth within a plant (Cichorium intybus)-soil system: a comparative study. Agriculture, Ecosystems, and Environment 58, 133-144.

Varco JJ, Frye WW, Smith MS \& MacKown CT (1993) Tillage effects on legume decomposition and transformation of legume and fertilizer nitrogen-15. Soil Science Society of America Journal 57, 750-756.

VAUGHN SF \& BOyDSTON RA (1997) Volatile allelochemicals released by crucifer green manures. Journal of Chemical Ecology 23, 2107-2116.

WARNES DD \& ANDERSEN RN (1984) Decline of wild mustard (Sinapis arvensis) seeds in soil under various cultural and chemical practices. Weed Science 32, 214-217. 
Westcott MP \& Mikkelsen DS (1987) Comparison of organic and inorganic nitrogen sources for rice. Agronomy Journal 79, 937-943.

Westoby M, Leishman M \& Lord J (1996) Comparative ecology of seed size and dispersal. Philosophical Transactions of the Royal Society of London Series B 351, 1309-1318.

WESTON LA (1996) Utilization of allelopathy for weed management in agroecosystems. Agronomy Journal 88, 860-866.

Wilson BJ \& Phipps PA (1985) A long-term experiment on tillage, rotation, and herbicide use for the control of Avena fatua in cereals. In: Proceedings 1985 British Crop Protection Conference - Weeds, Brighton, UK, 693-700.

Zhang J, Drummond FA \& Liebman M (1998) Effect of crop habitat and potato management practices on the population abundance of adult Harpalus rufipes (Coleoptera: Carabidae) in Maine. Journal of Agricultural Entomology 15, 63-74.

Zucconi F, Monaco A, Forte M \& De Bertoldi M (1985) Phytotoxins during the stabilization of organic matter. In: Composting of Agricultural and Other Wastes (ed. JKR Gasser), 73-86. Elsevier Applied Science Publishers, London, UK. 